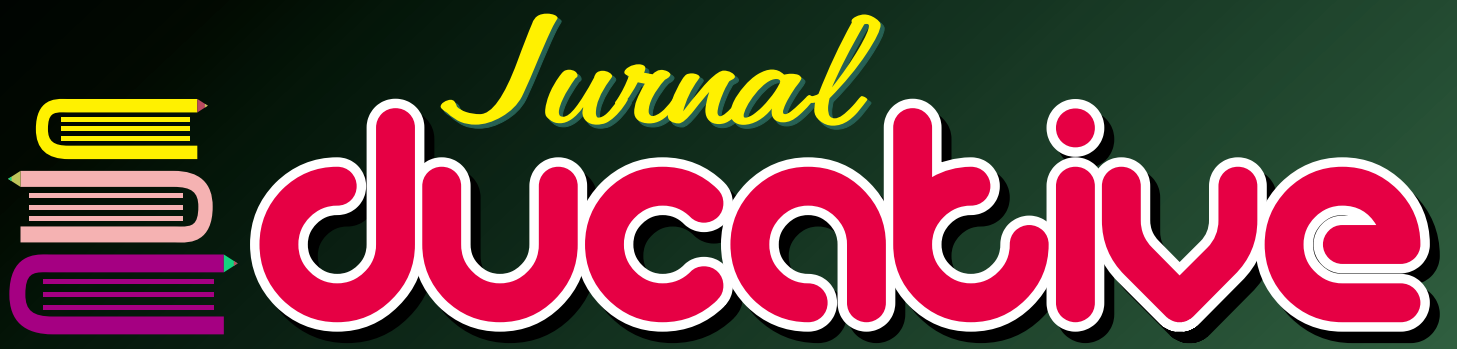 Journal of Educational Studies
}

Pengembangan Bahan Ajar Menulis Ringkasan dan Ikhtisar pada Mata Kuliah Pengembangan Keterampilan Menulis FKIP Universitas Baturaja Muhamad Doni Sanjaya, Muhamad Rama Sanjaya Upaya Meningkatkan Kemampuan Guru Menerapkan Penggunaan Bahan Ajar di SMA Negeri 3 Ogan Komering Ulu Aryanti Agustina

The Islamic Education Strategies Inlocal Culture Perspective of West Sumatera Society

Zulfani Sesmiarni, Junaidi, Darul Ilmi, Wedra Aprison

Problems In Learning Reading

(Case Study: Islamic Banking Students of IAIN Bukittinggi) Widya Syafitri

Teori Laactract dalam Persahabatan Generasi Millenial Qolbi Khoiri

e-Modul Computer Based Learning sebagai e-Resource Digital Literacy bagi Mahasiswa

Novrianti, Nofri Hendri, Ulfia Rahmi

Pengembangan Media Pembelajaran Mobile Learning berbasis Android Pada Mata Kuliah Kecerdasan Buatan Agus Nur Khomarudin, Liza Efriyanti

Meningkatkan Hasil Belajar Siswa Menggunakan Model Make a Match pada Mata Pelajaran IPS Kelas IV di SDN 11 OKU Yelmi Yunarti 


\title{
MENINGKATKAN HASIL BELAJAR SISWA MENGGUNAKAN MODEL MAKE A MATCH PADA MATA PELAJARAN IPS KELAS IV DI SDN 11 OKU
}

\author{
Yelmi Yunarti \\ Fakultas Keguruan dan Ilmu Pendidikan- Universitas Baturaja \\ E-mail:uniyelmiyunarti@gmail.com
}

Diterima : 15 Maret 2018 $\quad$ Direvisi:01 Mei $2018 \quad$ Diterbitkan : 30 Juni 2018

\begin{abstract}
Absract
The problem of this study is the low student learning outcome and not yet applied learning model make a match in the subject of IPS. This research is a classroom action research.The technique of data collection is by observation and test. To analyze the data of student learning outcome used t test technique, tobtained is 2,776 while at $t$ level $5 \%=2,05$, so tobtained $>$ t table or mathematically 2,05 is $<2,06$ it can be concluded that $t$ obtained $>$ than $t$ table. That is, Ho rejected an ha accepted because $t$ count $>t$ table. Thus, the hypothesis put forward that therte is a siginificant increase in learning outcomes between after and before tanght by using the model make a match acceptable the right.
\end{abstract}

Keywords: outcome, make a match, IPS

\begin{abstract}
Abstrak
Masalah dalam penelitian ini adalah rendahnya hasil belajar siswa dan belum diterapkannya model pembelajaran make a match pada mata pelajaran IPS. Jenis Penelitian ini merupakan penelitian tindakan kelas.Teknik pengumpulan data adalah dengan observasi dan tes. Untuk menganalisis data hasil belajar siswa digunakan teknik uji-t. Berdasarkan perhitungn uji t, hasil $\mathrm{t}$ hitung adalah 2,776 sedangkan pada harga t $5 \%=2,05$ dan $1 \%=2,06$, sehingga $\mathrm{t}$ hitung $>\mathrm{t}$ tabel atau secara matematis 2,05 $<2,776>2$, 06, maka dapat disimpulkan $\mathrm{t}$ hitung $>\mathrm{t}$ tabel. Terbukti " $\mathrm{t}_{\mathrm{o}}$ " > harga kritik " $\mathrm{t}$ tabel" ("t $\mathrm{t}_{\mathrm{o}}$ " lebih besar dari pada harga kritik " $\mathrm{t}$ tabel"). Artinya , Ho ditolak dan Ha diterima karena t hitung $>\mathrm{t}$ tabel. Dengan demikian, hipotesis yang dikemukakan yaitu terdapat peningkatan hasil belajar yang signifikan antara sesudah dan sebelum diajarkan dengan menggunakan model make a match" dapat diterima kebenarannya.
\end{abstract}

Kata Kunci: Hasil Belajar, Make a Match, IP

\section{Latar Belakang}

Pendidikan merupakan salah satu sektor yang paling penting dalam pembangunan nasional. Hal ini dikarenakan melalui sektor pendidikan dapat dibentuk manusia yang berkualitas, seperti yang disebutkan dalam Undang-Undang No. 20 Tahun 2003 Bab II menyatakan bahwa: Pendidikan nasional berfungsi mengembangkan kemampuan dan membentuk watak seperti peradapan bangsa yang bermartabat dalam rangka mencerdaskan kehidupan bangsa, bertujuan untuk berkembangnya potensi peserta didik agar menjadi manusia yang beriman dan bertaqwa kepada Tuhan Yang Maha Esa, berakhlak mulia, sehat, berilmu, cakap, kreatif, mandiri, menjadi warga negara yang demokratis serta bertanggung jawab.

Oleh karena itu untuk meningkatkan mutu pendidikan di Indonesia, pemerintah selalu merevisi kurikulum yang sudah ada selaras dengan perkembangan jaman, demikian pula dengan model pembelajaran yang diterapkan selalu mengalami perkembangan. 
Perkembangan dan kemajuan ilmu pengetahuan dan teknologi tersebut, membuka kemungkinan peserta didik (siswa) tidak hanya belajar di dalam kelas yang dibimbing oleh guru saja, akan tetapi peserta didik dapat belajar dari luar kelas seperti dari lingkungan masyarakat, pakar atau ilmuwan, birokrat, media cetak maupun media elektronik, serta sarana-sarana lain yang ada di sekitar kita.

Model pembelajaran Ilmu Pengetahuan Sosial (IPS) Terpadu bagi siswa hendaknya sesuai dengan kebutuhan anak usia sekolah menengah pertama yaitu antara 6- 12 tahun, dimana pada usia ini para pengajarnya yang akan berguna bagi mereka untuk dapat di terapkan dalam kehidupan mereka namun mudah untuk di mengerti oleh mereka karena pola pikir mereka yang masih sederhana yang hanya memikirkan hal-hal pada saat ini saja sehingga perlu untuk diterapkan model pembelajaran atau teknik yang dapat memungkinkan mereka untuk memahami hal ini

Pembelajaran Ilmu Pengetahuan Sosial khususnya di Sekolah Dasar bertujuan mengembangkan penalaran dan logika sehingga potensi intelektual dan kecerdasan siswa dapat diapresiasikan dan ditingkatkan bahkan diterapkan di lingkungan sekolah dan dalam kehidupan sehari-hari. Oleh karena itu, keberhasilan pembelajaran IPS memerlukan sistem pembelajaran yang mampu mengembangkan kemapuan siswa mengembangkan pemikiran dan penalaran melalui prinsip-prinsip IPS sehingga proses harus memiliki ketepatan, keakuratan, dan dapat dipertanggung jawabkan. Selain itu, dalam pembelajaran IPS guru harus mempertimbangkan keadaan dan kondisi siswa karena siswa memiliki potensi, latar belakang, dan karakteristik yang berbeda-beda dan sangat khas sehingga dalam pembelajaran daya serap siswa memahami serta menguasai materi pembelajaran bermacam-macam dan bervariasi.

Pada pembelajaran IPS kelas IV SDN 11 OKU masih banyak siswa yang mengangap bahwa mata pelajaran IPS membosankan dan sukar untuk dipahami, karena didalam mata pelajaran IPS banyak teorinya oleh karena itu siswa kurang bermita dalam mata pelajaran tersebut. Pelajaran IPS kurang menarik karena proses pembelajaran yang diterapkan masih monoton hanya berpusat pada metode ceramah dan tidak ada inovasi dalam menerapkan proses pembelajaran. Sedangkan faktor yang lain hanyalah faktor pendukung saja, misalnya sarana dan prasarana yang dibutuhkan dalam setiap kegiatan pembelajaran. Oleh karena itu siswa kurang aktif dalam mengikuti proses belajar mengajar dikarenakan kurang berpariasinya model pembelajaran, untuk meningkatkan motivasi siswa dalam proses belajar mengajar maka guru harus mengunakan model yang bervariasi. Dan pada akhirnya berpengaruh pada nilai siswa, rata-rata nilai yang dicapai oleh siswa masih dibawah KKM yang telah ditetapkan oleh sekolah, yaitu: 70 .

Dengan permasalahan yang muncul tersebut, dalam rangka meningkatkan hasil belajar IPS diperlukan strategi pembelajaran yang tepat dan model pembelajaran yang bervariasi. Strategi menurut Kozma dan Gafur secara umum menjelaskan bahwa strategi pembelajaran dapat diartikan sebagai setiap kegiatan yang dipilih, yaitu yang dapat memberikan fasilitas atau bantuan kepada peserta didik menuju tercapainya tujuan pembelajaran tertentu ${ }^{1}$. Para ahli menyusun model pembelajaran berdasarkan prinsipprinsip pembelajaran, teori-teori psikologi, sosiologi, analisis sistem, atau teori-teori lain yang mendukung. Joyce \& Weil berpendapat bahwa model pembelajaran adalah suatu

1 Hamzah Uno dan Muhammad, Belajar Dengan Pendekatan, Bumi Aksara, Jakarta, 2011, h.4. 
rencana atau pola yang dapat digunakan untuk membentuk kurikulum (rencana pembelajaran jangka panjang), merancang bahan-bahan pembelajaran, dan membimbing pembelajaran di kelas atau yang lain ${ }^{2}$.

Salah satu model yang dapat diterapkan dalam pembelajaran IPS adalah make a match, yakni suatu model pembelajaran yang dapat membiasakan para siswa menghadapi dan memecahkan masalah secara terampil, apabila menghadapi permasalahan di dalam kehidupan Model make a match ini juga dapat merangsang pengembangan kemampuan berpikir siswa secara kreatif dan menyeluruh, karena dalam proses pembelajarannya, siswa banyak melakukan mental dengan menyoroti permasalahan dari berbagai segi dalam rangka mencari pemecahan masalah ${ }^{3}$.

\section{Kajian Pustaka Belajar}

Belajar merupakan tindakan dan perilaku siswa yang kompleks ${ }^{4}$. Sebagai tindakan belajar hanya dialami oleh oleh siswa sendiri. Siswa adalah penentu terjadi atau tidak terjadinya proses belajar. Proses belajar terjadi berkat siswa memperoleh sesuatu yang ada dilingkungan sekitar. Lingkungan yang dipelajari oleh siswa berupa keadaan alam., benda-benda, tumbuhan, manusia,atau hal-hal yang dijadikan bahan belajar. Tindakan belajar tentang suatu hal tampak sebagai perilaku belajar yang tampak dari luar. Belajar adalah suatu proses usaha yang dilakukan seseorang untuk memperoleh suatu perubahan tingkah laku yang baru secara keseluruhan, sebagai hasil pengalamannya sendiri dalam interaksi dengan lingkungannya. Pada saat orang belajar, maka responsnya menjadi lebih baik.

2 Rusman, Model-Model Penelitian. Bandung: PT RajaGrafindo Persada, Bandung, 2010. h.132-133.

3 Ibid. h. 223.

${ }^{4}$ Dimyati dan Mudjiono, Belajar dan Pembelajaran, PT Rineka Cipta, Jakarta, 2009. h.7
Sebaliknya bila ia tidak belajar, maka responsnya menurun. Sedangkan menurut Jerume Brunner belajar adalah suatu proses aktif dimana siswa membangun pengetahuan baru berdasarkan pada pengalaman/pengetahuan yang sudah dimilikinya. Dalam pandangan kontruktivis belajar bukanlah semata-mata mentransfer pengetahuan yang ada diluar dirinya, melainkan belajar lebih pada bagaimana otak memproses dan menginterprestasikan pengalaman yang baru dengan pengetahuan yang sudah dimilikinya dalam format baru.

Dapat disimpulkan bahwa belajar merupakan proses perkembangan hidup manusia yang ditandai dengan adanya suatu perubahan tingkah laku karena adanya suatu pengalaman. Adapun prinsip belajar diantaranya ; perhatian dan motivasi, keaktifan, keterlibatan langsung, pengulangan, tantangan, balikan dan penguatan, perbedaan individual ${ }^{5}$. prinsip pebelajaran dapat meningkatkan motivasi anak didik, keaktifan dalam belajar, adanya pengalaman, pembelajaran yang berkelanjutan, adanya balikan dan penguatan serta adanya pengulangan dalam proses pembelajaran.

\section{Pembelajaran}

Pembelajaran merupakan suatu usaha sadar guru/ pengajar untuk membantu siswa atau anak didiknya agar mereka dapat belajar sesuai dengan kebutuhan minatnya. Pembelajaran adalah suatu usaha untuk membuat peserta didik belajar atau suatu kegiatan untuk membelajarkan peserta didik. pembelajaran secara simpel dapat diartikan sebagai produk interaksi berkelanjutan antara pengembangan dan pengalaman hidup.

Menurut La Iru dan Arihi secara harfiah pembelajaran proses,cara, perbuatan mempelajari dan perbuatan menjadikan orang

${ }^{5}$ ibid.h.42 
atau makhluk hidup belajar. ${ }^{6}$ Pembelajaran merupakan suatu proses atau upaya menciptakan kondisi belajar dalam emngembangkan kemmapuan minat dan bakat siswa secara optimal, sehingga kompetensi dan tujuan pembelajaran dapat tercapai. Dalam proses pembelajaran terjadi interaksi belajar dan mengajar dalam kondisi tertentu yang melibatkan beberapa unsur, baik unsur ekstrinsik maupun unsur instrinsik yang melekat pada diri siswa dan guru termasuk lingkungan.

\section{Hakikat Model Pembelajaran}

Mengingat tuntutan kompetensi yang harus dicapai oleh anak didik perlu danya perubahan dalam model pembelajaran. Kodel pembelajaran yang dikembangkan diharapkan dapat melayani dan memfasilitasi peserta didik untuk mampu berbuat dan melakukan sesuatu. Model pembelajaran adalah kerangka konseptual yang melukiskan prosedur yang sistematis dalam mengorganisasi pengalaman belajar untuk mencapai tujuan belajar tertentu dan berfungsi sebagai pedoman bagi perancang pembalajaran dan para pengajar dalam merencanakan aktivitas belajar dan mengajar. Model pembelajaran adalah suatu rencana atau pola yang dapat digunakan untuk membentuk kurikulum (rencana pembelajaran jangka panjang), merancang bahan-bahan pembelajaran, dan membimbing pembelajaran di kelas atau yang lain ${ }^{7}$. Model pembelajaran juga merupakan pola yang digunakan sebagai pedoman dalam merencanakan pembelajaran di kelas maupun tutorial. Model pembelajaran juga sebagai kerangka konseptual yang melukiskan prosedur yang sistematis dalam mengorganisasikan pengalaman belajar untuk mencapai tujuan belajar tertentu dan berfungsi

\footnotetext{
${ }^{6}$ Andi Prastowo, Pengembangan Bahan ajar Tematik Panduan Lengkap Aplikatif, DIVA Press,

Jogjakarta,2013. h.57

${ }^{7}$ Rusman, Model-model pembelajaran, Bumi Aksara, Jakarta, 2012. h.133
}

sebagai pedoman bagi perancang pembelajaran dan para pengajar dalam merencanakan dan melaksanakan aktivitas pembelajaran.

Berdasarkan pendapat di atas dapat disimpulkan bahwa model pembelajaran adalah suatu perencanaan yang sistematis dan sebagai pedoman untuk proses kegiatan belajar bagi guru. Dapat disimpulkan bahwa pembelajaran merupakan suatu proses ataupun serngkaian kegiatan untuk memberikan perubahn tingkah laku, maupun kemampuan berpikir yang di dapat dari tenaga pendidik.

\section{Model Pembelajaran Make a Match (Membuat Pasangan)}

Salah satu hal yang urgen yang perlu dipersiapkan oleh guru dalam proses pembelajaran adalah merancang model pembelajaran yang akan diterapkan. Keberhasilan pembelajaran salah satunya dapat dilihat dari kesesuaian model pembelajaran dengan karakteristik peserta didik. Model pembelajaran kooperatif dikembangkan berdasarkan teori belajar kontruktivis. Hal ini terlihat dari salah satu teori Vigotsky yakni bahwa fase mental yang lebih tinggi terserap dalam individu tersebut. Model pembelajaran kooperatif berbeda dengan pengajaran langsung. Model pembelajaran kooperatif dikembangkan untuk mencapai hasil belajar akademik, model ini juga efektif untuk mengembangkan keterampilan siswa. pembelajaran kooperatif sebagai falsafah tanggung jawab pribadi dan sikap menghormati sesama. Model pembelajaran kooperatif yang diterapkan disini adalah model make a match.

Model Make a Match (membuat pasangan) merupakan salah satu jenis dari metode dalam pembelajaran kooperatif ${ }^{8}$. Model ini dikembangkan oleh Lorna Curran (1994). Model pembelajaran make a match atau mencarai pasangan merupakan salah satu alternatif yang diterapkan kepada siswa. Model

${ }^{8}$ Ibid., hlm. 223. 
pembelajaran ini dimana guru menyiapkan kartu yang berisi soal atau permasalahan dan menyiapkan kartu jawaban kemudian siswa mencari pasangan kartunya. Model ini juga merupakan bagian dari pembelajaran kooperatif.

Salah satu keunggulan teknik ini adalah siswa mencari pasangan sambil belajar mengenai suatu konsep atau topik, dalam suasana yang menyenangkan. Penggunaan make a match dalam proses belajar mengajar memiliki tujuan yakni: untuk mendalami materi, mempelajari materi dan untuk selingan guru menyampaikan materi. Masing-masing tujuan memiliki tahapan persiapan dan media kartu yang digunakan. Khusus penggunaan model make a match yang dipakai untuk selingan (games) ketika proses belajar mengajar sedang berlangsung, akan tetapi siswa mengalami kejenuhan atau konsentrasi siswa tidak fokus lagi pada materi yang sedang dipelajarinya sehingga membutuhkan suasana segar dalam proses belajar mengajar.

Kelebihan model pembelajaran make a match antara lain : 1). Dapat meningkatkan aktivitas belajar siswa baik secara kognitif maupun fisik; 2). Metode itu menyenangkan; 3). Meningkatkan pemahaman siswa terhadap materi yang dipelajari dan dapat meningkatkan motivasi belajar siswa; 4). Efektif sebagai sarana melatih keberanian siswa untuk tampil presentasi; 5). Efektif melatih kedisiplinan siswa menghargai waktu untuk belajar?.

Sedangkan kelemahan model make a match antara lain : 1). Jika tidak dipersiapkan dengan baik, maka waktu akan terbuang; 2). Pada awal penerapannya, banyak siswa yang malu berpasangan dengan lawan jenisnya. 3). Jika guru tidak mengarahkan siswa dengan baik, akan banyak sisiwa yang kurang

\footnotetext{
${ }^{9}$ Miftahul Huda., Model-model Pengajaran dan Pembelajaran, Yogyakarta: Pustaka Pelajar, 2013.h.253-254
}

memperhatikan pada saat presentasi pasangan; 4). Guru harus hati-hati dan bijaksana saat memberikan hukuman pada siswa yang tidak mendapatkan pasangan, karena mereka bisa malu; 5). Menggunakan model ini secara terus menerus akan menimbulkan kebosanan ${ }^{10}$.

Penerapan metode ini dimulai dengan teknik, yaitu siswa disuruh mencari pasangan kartu.Salah satu keunggulan tehnik ini adalah siswa mencari pasangan sambil belajar mengenai suatu konsep atau topik dalam suasana yang menyenangkan. Langkah-langkah penerapan model make a match sebagai berikut : (1). Guru menyiapkan beberapa kartu yang berisi beberapa konsep atau topik yang cocok untuk sesi review, satu bagian kartu soal dan bagian lainnya kartu jawaban; (2). Setiap siswa mendapatkan sebuah kartu yang bertuliskan soal/jawaban; (3). Tiap siswa memikirkan jawaban/soal dari kartu yang dipegang; (4). Setiap siswa mencari pasangan kartu yang cocok dengan kartunya. Misalnya: pemegang kartu yang bertuliskan nama tumbuhan dalam bahasa Indonesia akan berpasangan dengan nama tumbuhan dalam bahasa latin (ilmiah); (5). Setiap siswa yang dapat mencocokkan kartunya sebelum batas waktu diberi poin; (6). Jika siswa tidak dapat mencocokkan kartunya dengan kartu temannya (tidak dapat menemukan kartu soal atau kartu jawaban) akan mendapatkan hukuman, yang telah disepakati bersama; (7). Setelah satu babak, kartu dikocok lagi agar tiap siswa mendapat kartu yang berbeda dari sebelumnya, demikian seterusnya; (8). Siswa juga bisa bergabung dengan 2 atau 3 siswa lainnya yang memegang kartu yang cocok; (9).Guru bersama-sama dengan siswa membuat kesimpulan terhadap materi pelajaran ${ }^{11}$.

Pada penerapan metode make a match, diperoleh beberapa temuan bahwa metode

\footnotetext{
${ }^{10}$ Ibid 11 Ibid, hlm.223.
} 
make a match dapat memupuk kerja sama siswa dalam menjawab pertanyaan dengan mencocokkan kartu yang ada di tangan mereka, proses pembelajaran lebih menarik dan nampak sebagian besar siswa lebih antusias mengikuti proses pembelajaran, dan keaktifan siswa tampak sekali pada saat siswa mencari pasangan kartunya masing-masing.

\section{Mata Pelajaran Ilmu Pengetahuan Sosial (IPS)}

Istilah Pendidikan IPS dalam menyelengarakan pendidikan di Indonesia masih relatif digunakan. Ilmu Pengetahuan Sosial (IPS) merupakan integrasi dari beragai cabang ilmu-ilmu sosial seperti: sosiologi, sejarah, hukum, budaya, ekonomi, geografi dan politik. Kurikulum pendidikan IPS tahun 1994 sebagaimana yang telah dikatakan Hamid Hasan (1990), merupakan fungsi dari berbagai disiplin ilmu. Mortorella (1987) mengatakan bahwa pembelajaran IPS lebih menekankan pada aspek "pendidikan" dari pada "transfernkonsep" karena dalam pembelajaran pendidikan IPS siswa diharapkan memperoleh pemahaman terhadap sejumlah konsep dan mengembangkan serta melatih sikap, nilai, moral, dan keterampilannya ${ }^{12}$. Dengan demikian, pembelajaran pendidikan IPS haru diformulasikan pada aspek kependidikannya.

Gross (1978) menyebutkan bahwa tujuan pendidikan IPS adalah untuk mempersiapkan siswa menjadi warga negara yang baik dalam kehidupan di masyarakat. Menurut Kosasih (1994) Ilmu pengetahuan sosial juga membahas hubungan antara manusia dengan lingkungannya, Lingkungan masyarakat dimana anak didik tumbuh dan berkembang sebagai bagian dari masyarakat, dihadapkan pada berbagai permasalahan yang

\footnotetext{
${ }^{12}$ Etin Solihatin dan Raharjo, Cooperative Learning Analisis Pembelajaran IPS, Bumi Aksara, Jakarta, 2005, hlm. 14 .
}

ada dan terjadi di lingkungan sekitarnya ${ }^{13}$. Pendidikan IPS berusaha membantu peserta didik dalam memecahkan permasalahan yang dihadapi sehingga akan menjadikannya semakin mengerti dan memahami lingkungan sosial masyarakatnya

Pada dasarnya tujuan dari pendidikan IPS adalah untuk mendidik dan memberi bekal kemampuan dasar kepada siswa untuk mengembangkan diri sesuai dengan bakat, minat, kemampuan, dan lingkungannya, serta berbagai bekal siswa untuk melanjutkan pendidikan ke jenjang yang lebih tinggi. Berdasarkan pengertian dan tujuan dari pendidikan IPS, tampaknya dibutuhkan suatu pola pembelajaran yang mampu menjembatani tercapainya tujuan tersebut. Kemampuan dan keterampilan guru dalam memilih dan menggunakan berbagai model, metode dan strategi pembelajaran senantiasa terus ditingkatkan, agar pembelajaran Pendidikan IPS benar-benar mampu mengondisikan upaya pembekalan kemampuan dan keterampilan dasar bagi peserta didik untuk menjadi manusia dan warga negara yang baik. Pola pembelajaran pendidikan IPS menekankan pada unsur pendidikan dan pembekalan pada peserta didik. Penekanan pembelajarannya bukan sebatas pada upaya mencecoki atau menjejali peserta didik dengan sejumlah konsep yang bersifat hafalan belaka, melainkan terletak pada upaya agar mereka mampu menjadikan apa yang telah dipelajarinya sebagai bekal dalam memahami dan ikut serta dalam melakoni kehidupan masyarakat lingkungannya, serta sebagai bekal bagi dirinya untuk melanjutkan pendidikan ke jenjang yang lebih tinggi.

\section{Hasil belajar}

Hasil belajar adalah sebagai tingkat penguasaan pengetahuan yang dicapai oleh siswa dalam mengikuti proses belajar mengajar

\footnotetext{
${ }^{13}$ Ibid.hlm. 14-15
} 
sesuai dengan tujuan pendidikan yang ditetapkan. hasil belajar merupakn hal yang penting untuk dijadikan sebagai tolak ukur sejauhmana keberhasilan seorang siswa dalam belajar. dari hasil belajar seorang guru dapat menilai apakah proses pembelajaran yang dilakukan berhasil atau tidaknya, untuk selanjutnya bisa diterapkan atau tidak pada proses pembelajaran selanjutnya.

Hasil belajar merupakan gambaran tingkat penguasaan siswa terhadap sasaran belajar pada topik bahan yang dieksperimenkan yang diukur berdasarkan jumlah skor jawaban benar pada soal yang disusun sesuai dengan sasaran belajar.Terdapat tiga ranah hasil belajar sesuai dengan pendapat Bloom, Krathwol dan Anderson sebagai berikut :

\section{Ranah Kognitif}

Tujuan pembelajaran pada ranah kognitif erat kaitannya dengan kemampuan berpikir dan kemampuan memberi alasan atau rasional. Kategori kemampuan dalam domain kognitif antara lain : a). Mengingat, kompetensi pada tingkat ini berisi kemampuan dalam mengingat kembali bahan atau materi yang telah dipelajari dan menyampaikan ingatannya bila diperlukan; b). Memahami, level pemahaman berisi kemampuan dalam mebuat interpretasi yang sederhana dari pengetahuan yang telah dipelajari; c). Menerapkan, berisi kemampuan menggunakan prinsip, teori dan pengetahuan yang telah dipelajari ke dalam situasi baru; d). Menganalisis, mempunyai makna mengurai bahan atau materi pelajaran yang kompleks menjadi komponen-komponen yang lebih sederhana sehingga mudah untuk dipelajari; e). Menilai, kemampuan seseorang sesuatu dari berbagai pertimbangan dan pemikiran kritis dalam; f). Menciptakan,kemampuan menggabungkan komponen-komponen pengetahuan yang telah dipelajari menjadi sesuatu yang baru atau menciptakan sesuatu.

\section{Ranah Afektif}

Ranah afektif berisi kemampuan yang berkaitan dengan konsep, perasaan, penghayatan dan emosi. Ranah afektif sukar untuk dirumuskan, hal ini disebabkan sifat emosional, perasaan, dan sikap seseorang sulit diamati seperti halnya kompetensi lain pada ranah kognitif. Ranah afektif terbagi dalam lima tingkatan yaitu penerimaan, pemberian tanggapan, penghitungan atau pemberian nilai, pengorganisasian atau pengaturan, pembentukan karakter atau pembentukan nilai

\section{Ranah Psikomotor}

Ranah psikomotor pada umumnya relevan dengan pembelajaran olah raga, drama, seni dan hal-hal yang sifatnya vokasional. namun pada dasarnya semua jenis pembelajaran memilki keterkaitan dengan ranah kognitif. Harrow (1972) mengemukakan empat tingkatan ranah psikomotor yaitu: a). gerakan fundamental, gerakan fundamental merupakan gerakan dasar yang diperlukan untuk melakukan gerakan yang lebih tinggi tingkatannya; b). gerakan generik, merupakan kemampuan dalam melakukan gerakan dasar yang telah disempurnakan dengan arahan dan pengawasan; c). gerakan ordinatif, tingkat gerakan ordinatif adalah kemampuan dalam melakukan kegiatan secara independen; d). gerakan kreatif, gerakan kreatif memilki makna adanya unjuk kemampuan dalam melakukan keterampilan yang bersifat unik dan asli.

\section{Metode Penelitian}

Jenis penelitian adalah penelitian tindakan kelas. Mc.Niff menegaskan bahwa "Dasar utama dilaksanakan penelitian tindakan kelas adalah untuk perbaikan proses pembelajaran di kelas ${ }^{14}$. Penelitian tindakan kelas adalah salah satu penelitian yang dapat dilaksanakan guru sebagai alternatif pilihan untuk menemukan cara dalam rangka

${ }^{14}$ Suharsimi Arikunto dan Suhadrjono, Penelitian Tindakan kelas,Rineka Cipta, Jakarta, 2007, h.106 
meningkatkan mutu atau kualitas proses pembelajaran di sekolah ${ }^{15}$. Lokasi penlitian dilakukan di SD Negeri 11 OKU dan yang menjadi sasaran dalam penelitian ini adalah siswa kelas IV yang berjumlah 20 orang. Penelitian tindakan kelas ini dilakukan melalui kegiatan mengumpulkan data yang berguna dalam meningkatkan hasil belajar melalui 3 siklus sehingga dapat diketahui hasil belajar siswa pada mata pelajaran IPS. Dalam hal ini objek yang diteliti adalah hasil belajar siswa kelas IV SD Negeri 11 OKU .Adapun subjek penelitian ini adalah kelas IV SD Negeri 11 OKU dengan jumlah siswa 20 orang.

Menurut Arikunto dkk (2008: 16), terdapat empat tahapan yang lazim dilalui dalam penelitian tindakan kelas, yaitu a) Perencanaan, b) Pelaksanaan, c) Pengamatan, d) Refleksi. Secara jelas siklus tergambar seperti berikut. Prosedur kerja dalam penelitian ini merupakan siklus kegiatan yang terdiri dari perencanaan - pelaksanaan pengamatan - refleksi ${ }^{16}$. Siklus direncanakan minimal 2 siklus dengan ketentuan apabila ketuntasan belajar yang diharapkan terpenuhi, maka penelitian tindakan ini dianggap telah menyelesaikan permasalahan yang dihadapi. Secara jelas siklus tergambar pada bagan sebagai berikut.

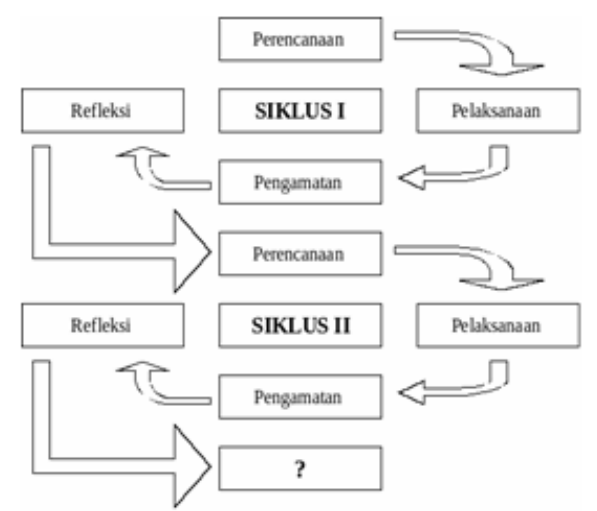

Bagan 1.1 Model penelitian tindakan

\footnotetext{
15 Susilo, Panduan Penelitian Tindakan Kelas,Pustaka Book Publisher, Yogyakarta, 2008.h.26

16 Suharsimi Arikunto dan Suhardjono, Penelitian tindakan kelas, Bumi Aksasa, Jakarta, 2008, h.16
}

Berdasarkan model tersebut, maka penelitian diawali dengan perencanaan, pelaksanaan, pengamatan dan refleksi sebagai siklus 1 . Kemudian siklus II ditentukan dari hasil refleksi siklus I dengan memperbaiki perencanaan dan pemecahan masalah yang ada pada siklus 1, kemudian dari refleksi siklus II untukmemantapkan hasil pengamatan dan begitu seterusnya pada siklus selanjutnya. Pada perencanaan, kegiatan yang dilakukan mengidentifikasi masalah yang akan dilakukan dalam penelitian mencakup diantaranya, identifikasi masalah dan alternatif pemecahan masalah, merencanakan pembelajaran dengan model make a match, menetapkan standar kompetensi dan kompetensi dasar, memilih bahana pelajaran yang sesuai dengan mata pelajaran IPS, menentukan rencana pembelajaran IPS, mempersiapkan sumber dan alat yang dibutuhkan dalam pembelajaran, mengembangkan format evaluasi berupa tes yang akan dikerjakan oleh siswa, mengembangkan format observasi. Pelaksanaan, pada tahap pelaksanaan merujuk kepada perencanaan yang telah dibuat sebelumnya dan pelaksaan kegiatan ini sesuai dengan langkah-langkah model make a match. Pengamatan, pada tahap ini melakukan perekaman data yang meliputi proses dan hasil dari pelaksanaan kegiatan dan menilai hasil tindakan dengan menggunakan hasil tes yang telah dikerjakan siswa.Refleksi, pada tahap ini melakukan analisis data pada proses, masalah dan hambatan yang dialami serta memperbaiki pelaksanaan tindakan sesuai hasil evaluasi untuk digunakanpada siklus selanjutnya.

Teknik pengumpulan data, antara lain:1) Tes. Tes sebagai alat ukur yang diberikan kepada individu untuk mendapatkan jawaban-jawaban yang diharapkan baik secara tertulis atau secara lisan atau secara perbuatan. Jenis tes yang akan digunakan sebagai alat pengukur adalah tes tertulis. 2) Observasi. Observasi sebagai alat pengumpul data banyak 
digunakan untuk mengukur tingkah laku individu ataupun proses terjadinya suatu kegiatan yang dapat diamati baik dalam situasi yang sebenarnya maupun dalam situasi buatan. Untuk menghitung persentase peningkatan keaktifan siswa sebagai berikut.

Rumus yang digunakan ${ }^{17}$

$$
\mathbf{P}=\frac{f}{N} \times 100 \%
$$

Untuk melihat perbedaan dari masingmasing tes hasil belajar pada setiap siklus dan perbedaan hasil pra-tindakan dengan setelah tindakan digunakan rumus uji tes

sebagai

yang

$$
T_{o}=\frac{M_{d}}{S E_{m_{d}}} \text { digunakan }^{18}
$$

\section{Hasil Penelitian Prasiklus}

Prasiklus adalah langkah awal mengadakan siklus 1 pada penelitian atau kondisi siswa sebelum melaksanakan pembelajaran dengan menggunakan model make a match. Hal ini dilakukan untuk mengetahui sejauhmana kemampuan dan hasil belajar siswa pada mata pelajaran IPS. Adapun kriteria Ketuntasan Minimal (KKM yang ditetapkan adalah 70. Berdasarkan hasil analisis pengamatan bahwa sebagian siswa masih pasif dalam belajar IPS. Sedangkan dari hasil tes prasiklus masih dibawah KKM yang telah ditetapkan.

\section{Siklus1}

Penelitian tindakan kelas (PTK) ini dilaksanakan di kelas 1V SD Negeri 11 OKU dengan jumlah siswa 20 orang. Penelitian

17 Anas Sudijono, 2008. Statistik Pendidikan, Raja Grafindo Persada, Jakarta, 2008.h.43

18 Ibid., .h.305 tindakan kelas (PTK) ini dilaksanakan pada semester genap dalam mata pelajaran Ilmu pengetahuan sosial . Penelitian tindakan kelas ini dilakukan dalam tiga siklus pembelajaran, dan pembelajaran tiap siklus dilakukan dalam dua hal tatap muka dengan alokasi waktu 2 jam pelajaran per siklusnya. Berdasarkan data yang telah peneliti sampaikan, maka rata-rata nilai yang diperoleh siswa pada prasiklus 55 . Hasil belum memenuhi Kriteria Ketuntasan Maksimal (KKM) yang ditetapkan yaitu 70, untuk itu perlu diadakan penelitian tindakan kesiklus I. Setelah pada siklus I dilaksanakan, berdasarkan pengamatan terhadap pelaksanaan penelitian tindakan kelas siklus I dapat diuraikan sebagai ber

Pengamatan dilakukan terhadap siswa selama proses pembelajaran berlangsung dengan menggunakan format pengamatan. Berdasarkan hasil pengamatan dengan menggunakan lembar observasi, dapat disimpulkan hal-hal sebagai berikut : 1). Sebanyak 50\% siswa tidak memperhatikan penjelasan guru dengan cermat.; 2). Akan tetapi masih ada 50\% siswa yang tidak aktif dalam menjawab pertanyaan; 3). Masih ada siswa ada 30\% siswa yang tidak mengajukan pertanyaan; 5). Hanya 40\% siswa yang mencari pasangan kartu yang dimilikinya; 6). Sebanyak 60\% siswa yang menunjukkan hasil penemuan pasangan kartu yang mereka temukan kepada guru; 7). Ada 10 siswa yang menulis isi dari kartu yang mereka temukan ke dalam buku latihan selebihnya sebanyak $50 \%$ orang siswa hanya mengerjakan soal tes dalam keadaan tidak serius.

Sesuai dengan karakteristik penelitian tindakan kelas maka sebelum pelaksanaan siklus, diberikan tes awal yang bertujuan untuk melihat kemampuan awal peserta didik sebelum pelaksanaan siklus. Berdasarkan hasil prasiklus rata-rata hasil belajar peserta didik adalah 49, 00 dan siklus I terjadi peningkatan rata-rata hasil belajar 59, 5. Berdasarkan 
perhitungan, terbukti " $\mathrm{t}$ " > harga kritik " $\mathrm{t}$ tabel (" $t$ " lebih besar dari pada harga kritik " $t$ tabel) dengan demikian, hipotesis nihil ditolak dan hipotesis alternative $(\mathrm{Ha})$, "untuk peserta didik di kelas IV ada (terdapat) perbedaan hasil belajar yang signifikan antara sesudah dan sebelum diajarkan menggunakan model make a match pada mata pelajaran ilmu pengetahuan sosial diterima. Akan tetapi, dengan melihat daya serap siswa yang memenuhi kriteria daya serap yang ditetapkan, maka perlu dilakukan penelitian tindakan kelas siklus II.

Berdasarkan hasil belajar pada siklus I, dibandingkan dengan hasil belajar pada pra siklus, teryata siswa yang mendapat nilai sama dengan atau di atas 60 adalah 9 orang siswa, sementara sebelum dilaksanakan pembelajaran siklus I terdapat 5 orang siswa, artinya terdapat 7 siswa yang mengalami peningkatan hasil belajar dari pra sikus ke siklus I, akan tetapi jika ditinjau secara individual masih ada siswa yang nilainya belum mencapai KKM dan perlu diadakan pembelajaran siklus II.

Hasil dari pengmatan dan hasil belajar diadakan refleksi terhdap tindakan yang dilakukan pada siklus 1. Target evaluasi pada siklus 1 belum tercapai, maka dilanjutkan pada siklus berikutnya yaitu siklus II.

\section{Siklus II}

Berdasarkan hasil observasi dan refleksi dapat diidentifikasi masalah-masalah yang menghambat kenaikan hasil belajar siswa sehingga dapat diambil langkah perbaikan siklus II ini. Hasil pengamatan dengan menggunakan lembar observasi, dapat disimpulkan hal-hal sebagai berikut : 1). Sebanyak 30\% siswa tidak memperhatikan penjelasan guru dengan cermat; 2). Masih ada $50 \%$ siswa belum melaksanakan instrumen guru dengan baik. Ada 10 siswa menunjukkan sikap prilaku terpuji; 3). Sebanyak $40 \%$ siswa yang tidak mencari pasangan kartu yang dimilikinya; 4). Hanya
60\% siswa menunjukkan hasil penemuan pasangan kartu yang mereka temukan kepada guru; 7). Ada 10 siswa yang menulis isi dari kartu yang mereka temukan ke dalam buku latihan; 8). Sebaliknya sebanyak 50\% siswa hanya mengerjakan soal tes dalam keadaan tidak serius.

Setelah pembelajaran siklus II dilaksanakan, pada akhir pembelajaran dilaksanakan tes dengan nilai siswa sebagai berikut Berdasarkan perhitungan, terbukti " $\mathrm{t}$ " $>$ harga kritik " $t$ "tabel (" $\mathrm{t}$ " lebih besar dari pada harga kritik " $\mathrm{t}$ " tabel) dengan demikian, hipotesis nihil di tolak dan hipotesis alternative (Ha), " untuk peserta didik di kelas IV ada (terdapat) perbedaan hasil belajar yang signifikan antara siklus I dan siklus II dalam pembelajaran dengan menggunakan Model Make a match pada mata pelajaran ilmu pengetahuan sosial diterima. Akan tetapi, dengan melihat daya serap siswa yang belum memenuhi kriteria daya serap yang ditetapkan $\geq 60$, maka perlu dilaksanakan tindakan kelas siklus III. Berdasarkan perhitungan tersebut dapat di simpulkan bahwa nilai rata- rata secara klasikal dapat di terima, nilai individu juga dapat di terima, tetapi untuk menyakinkan akan kebenaran hasil penelitian, maka peneliti tetap akan melakukan pembelajaran siklus III

\section{Siklus III}

Berdasarkan hasil observasi dan refleksi dapat diidentifikasi masalah-masalah yang menghambat kenaikan hasil belajar siswa sehingga dapat diambil langkah perbaikan pada siklus III ini. Hasil pengamatan dengan menggunakan lembar observasi, dapat disimpulkan hal-hal sebagai berikut : 1). Sebanyak $30 \%$ siswa yang tidak memperhatikan penjelasan guru dengan cermat 2). Masih ada 30\% siswa yang tidak melaksanakan instrumen guru dengan baik; 3). Masih ada $40 \%$ siswa yang belum menunjukkan sikap prilaku terpuji; 4). 
Sebanyak 10\% siswa yang belum mencari pasangan kartu yang dimilikinya; 5). Hanya $80 \%$ siswa yang menunjukkan hasil penemuan pasangan kartu yang mereka temukan kepada guru; 6). Ada 18 orang siswa yang telah menulis isi dari kartu yang mereka temukan ke dalam buku latihan 7). sebaliknya $10 \%$ orang siswa hanya mengerjakan soal tes dalam keadaan tidak serius

Berdasarkan perhitungan tersebut, terbukti " $\mathrm{t}$ " > harga kritik "t tabel (" $\mathrm{t}$ " lebih besat dari pada harga kritik "t tabel) dengan demikian, hipotesis nihil di tolak dan hipotesis alternative (Ha), "untuk peserta didik di kelas IV ada (terdapat) perbedaan hasil belajar yang signifikan antara siklus II dan siklus III dalam pembelajaran menggunakan model make a match pada mata pelajaran ilmu pengetahuan sosial diterima. Berdasarkan deskripsi hasil belajar pada siklus I, siklus II dan siklus III memperhatikan bahwa penggunaan model make a match pelajaran ilmu pengetahuan dapat meningkatkan hasil belajar siswa. Berdasarkan perhitungan uji $t$, terbukti “ $t$ " > harga kritik " $t$ tabel (" $t$ "lebih besar pada harga kritik " $t$ tabel) dengan demikian, hipotesis nihil di tolak dan hipotesis alternative $(\mathrm{Ha})$, "untuk peserta didik di kelas IV ada (terdapat) perbedaan hasil belajar yang signifikan antara sesudah dan sebelum diajarkan dengan menggunakan model make a match diterima. Berikut ini peningkatan hasil belajar siswa persiklus.

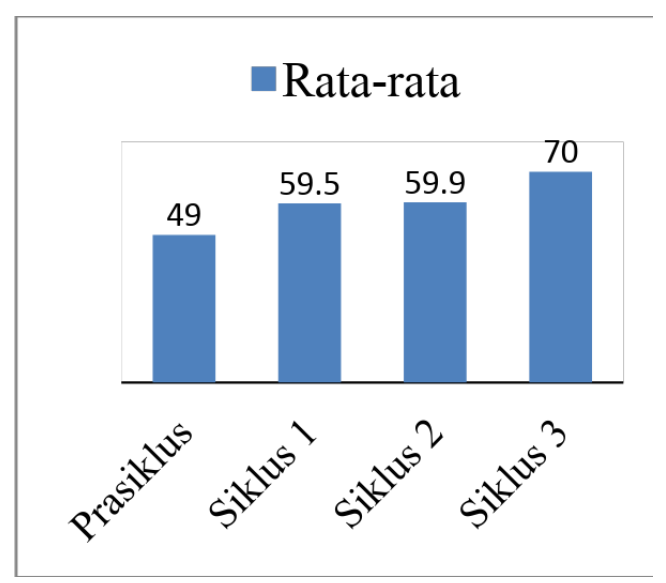

Gambar peningkatan hasil belajar tersebut berkaitan dengan pelaksanaan pembelajaran dengan menggunakan model make a match pada mata pelajaran ilmu pengetahuan sosial. Model make a match pada mata pelajaran ilmu pengetahuan ini membantu mengaitkan antara materi yang diajarkan dengan situasi dunia nyata siswa dan mendorong siswa membantu hubungan antara pengetahuan yang dimiliki dengan penerapannya dalam kehidupan mereka.

\section{Pembahasan}

Berdasarkan hasil pengamatan dan hasil belajar terjadi perubahan sikap siswa terhadap mata pelajaran IPS dari prasiklus sampai siklus III. Hal ini berarti pembelajaran IPS menggunakan model make a match dapat mendorong siswa untuk ikut terlibat aktif dalam kegiatan di kelas. Model pembelajaran ini menyuruh siswa berpikir sekaligus melakukan proses interaksi sosial dengan teman sekelasnya.

Peningkatan dan pencapaian hasil belajar yang sudah sesuai dengan yang diharapkan tidak lepas dari peran guru selama proses pembelajaran dengan menggunakan model make a match, karena guru merupakan salah satu komponen yang mempengaruhi hasil belajar siswa. Dalam kaitan pelaksanaan pembelajaran model make a match, guru hanya bertindak sebagai fasilitator yang hanya mengarahkan siswa dalam bertindak, selebihnya siswa diberi kebebasan untuk menerjemahkan arahan guru tersebut dalam pembelajaran. Melalui pembelajaran aktif dapat berperan sebagai fasilitator, bertugas memfasilitasi pembelajaran yang berlangsung pada diri peserta didik, sehingga mereka memperoleh pengalaman belajar yang nyata dan otentik. Dengan memfasilitasi pembelajaran berarti guru berusaha mengajak dan membawa seluruh peserta didik yang ada dikelasnya untuk berpartisipasi. memfasilitasi 
pembelajaran bukanlah hal yang gampang jika guru tidak memiliki cukup pemahaman tentang psikologi dan teori pemahaman model pembelajaran seperti halnya model pembelajaran make a match.

Untuk itu upaya yang dapat dilakukan guru agar hasil belajar siswa dapat lebih optimal adalah dengan mempertinggi mutu pengajaran dan kualitas proses pembelajaran. Berbicara tentang mutu pembelajaran artinya mempersoalkan bagaimana kegiatan pembelajaran yang dilakukan selama ini berjalan dengan baik sesuai dengan apa yang diharapkan. Dalam meningkatkan kualitas pembelajaran, maka kita harus memperhatikan beberapa komponen sebagai berikut : (2). Siswa dan guru; (2). Kurikulum; (3). Sarana dan prasarana pendidikan; (4). Pengelolaan sekolah meliputi : pengelolaan kelas, guru, siswa, sarana dan prasarana, peningkatan tata tertib dan kepemimpinan; (5). Pengelolaan dana; (6). Evaluasi; (7). Kemitraan, meliputi hubungan sekolah dan lembaga lain ${ }^{19}$

Keaktifan siswa terhadap pembelajaran dengan menggunakan model make a match pada mata pelajaran ilmu pengetahuan sosial juga dapat mempengaruhi hasil belajar siswa. Berdasarkan hasil pengamatan dari siklus I sampai siklus III teryata keaktifan siswa juga mengalami peningkatan. Aspek yang diamati untuk mengukur keaktifan siswa dalam proses pembelajaran meliputi siswa memperhatikan penjelasan guru dengan cermat, siswa melaksanakan instrumen guru dengan baik, siswa menunjukkan sikap prilaku terpuji, siswa mencari pasangan kartu yang dimilikinya, siswa menunjukkan hasil penemuan pasangan kartu yang mereka temukan kepada guru, siswa menulis isi dari kartu yang mereka temukan ke dalam buku latihan. Untuk aspek

19 Martinis Yamin dan Maisah, Manajemen Pembelajaran kelas Strategi meningkatkan mutu pembelajaran,Jakarta ; Gaung Persada, 2009.h.164-166 siswa memperhatikan penjelasan guru dengan cermat terjadi peningkatan persentase jumlah siswa dari siklus I sampai III, yaitu 50\% pada siklus I, pada siklus II menjadi 70\%. Keaktifan siswa dalam belajar merupakan hal yang penting dan mendasar yang harus dipahami dan dikembangkan setisp guru dalam proses pembelajaran sehingga keaktifan siswa perlu digali dari potensi-potensi mereka yang diaktualisasikan melalui aktifitasnya untuk mencapai tujuan pembelajaran. Belajar aktif ditunjukkan dengan adanya ketertiban intelektual dan emosional yang tinggi dalam proses belajar. Siswa diberikan kesempatan untuk berdiskusi mengemukakan pendapat dan idenya, mengadakan eksplorasi terhadap materi yang dipelajarinya serta menfasirkan hasilnya secara bersama-sama di dalam kelompok.

Berdasarkan hasil penelitian bahwa model pembelajaran make a match berbantuan kartu bergambar dapat meningkatkan hasil belajar IPS, Hal ini dibuktikan dengan ketuntasan hasil belajar siswa. Dari hasil pembahasan dapat disimpulkan bahwa unsur sistem pembelajaran yang utama adalah guru dan siswa, jika keduanya dapat bekerjasama dengan kompak dan terarah, maka kendala yang dihadapi dalam pembelajaran dapat teratasi. Dengan model pembelajaran make a match materi pembelajaran dapat dengan cepat dipahami oleh siswa.

\section{Kesimpulan}

Berdasarkan hasil penelitian terdapat peningkatan hasil belajar siswa. Peningkatan hasil belajar tersebut dapat dilihat dari hasil pengamatan peneliti selama proses pembelajaran berlangsung. Hal ini ditandai dengan meningkatnya keaktifan dan keseriusan siswa dalam mengikuti pelajaran terjadi peningkatan peningkatan nilai rata-rata hasil belajar siswa . Berdasarkan perhitungan uji $t$, terbukti " $t$ " > harga kritik " $t$ tabel (" $t$ " 
lebih besar dari pada harga kritik " $\mathrm{t}$ " tabel) dengan demikian, hipotesis nihil ditolak dan hipotesis alternatif $(\mathrm{Ha})$ untuk peserta didik kelas IV ada (terdapat) perbedaan hasil belajar yang signifikan antara sesudah dan sebelum diajarkan dengan menggunakan model make a match pada mata pelajaran ilmu pengetahuan sosial.

\section{Saran}

Berdasarkan penelitian yang telah dilakukan, peneliti mengajukan beberapa saran sebagai berikut : Dalam penerapan model pembelajaran make a match, guru menyiapkan secara matang perancangan pembelajaran, instrumen, ataupun pengelolaan waktu dan membuat susasana kelas kondusif agar siswa menerima pembelajaran. Siswa dituntut untuk lebih aktif dan serius dalam mengikuti proses pembelajaran.

\section{Daftar Pustaka}

Arikunto, Suharsimi dkk. 2007. Penelitian Tindakan Kelas. Jakarta: Bumi Aksara 2008. Penelitian Tindakan kelas. Jakarta: Bumi Aksara

Dimyatai dan Mudjiono, 2009. Belajar dan pembelajaran. Jakarta ; Pt Rineka Cipta

Huda, Miftahul.2013. Model-model Pembelajaran dan pengajaran. Yogyakarta: Pustaka pelajar

Uno Hamzah \& Nurdin, Mohamad. 2011. Belajar Dengan Pendekatan. Jakarta: Bumi Aksara

Prastowo, Andi..2013. Pengembangan Bahan Ajar Tematik Panduan lengkapAplikatif. Jogjakarta; DIVA Press

Rusman. 2010. Model-Model Pembelajaran. Bandung: PT RajaGrafindo Persada

Sudijono, Anas. 2008. Statistik Pendidikan. Jakarta: Raja Grafindo Persada

Susilo. 2007.Panduan penelitian Tindakan Kelas. Yogyakarta:Pustaka Book Publisher
Solihatin, Etin \& Raharjo. 2005. Cooperative Learning Analisis Pembelajaran IPS. Jakarta : Bumi Aksara

Yamin, Martinis dan Maisah.2009. Manajemen Pembelajaran kelas strategi meningkatkan mutu pembelajaran. Jakarta : Gaung Persada 